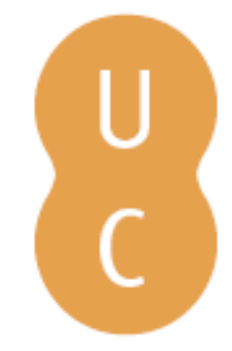

\title{
pommalina
}

\section{Assigning dates to burned areas in Portugal based on NIR and the reflected component of MIR as derived from MODIS}

Autor(es): $\quad$ Panisset, Jéssica; Libonati, Renata; DaCamara, Carlos C.; Barros, Ana

Publicado por: Imprensa da Universidade de Coimbra

URL

persistente: URI:http://hdl.handle.net/10316.2/34159

DOI: $\quad$ DOI:http://dx.doi.org/10.14195/978-989-26-0884-6_183

Accessed : $\quad$ 26-Apr-2023 05:06:20

A navegação consulta e descarregamento dos títulos inseridos nas Bibliotecas Digitais UC Digitalis, UC Pombalina e UC Impactum, pressupõem a aceitação plena e sem reservas dos Termos e Condições de Uso destas Bibliotecas Digitais, disponíveis em https://digitalis.uc.pt/pt-pt/termos.

Conforme exposto nos referidos Termos e Condições de Uso, o descarregamento de títulos de acesso restrito requer uma licença válida de autorização devendo o utilizador aceder ao(s) documento(s) a partir de um endereço de IP da instituição detentora da supramencionada licença.

Ao utilizador é apenas permitido o descarregamento para uso pessoal, pelo que o emprego do(s) título(s) descarregado(s) para outro fim, designadamente comercial, carece de autorização do respetivo autor ou editor da obra.

Na medida em que todas as obras da UC Digitalis se encontram protegidas pelo Código do Direito de Autor e Direitos Conexos e demais legislação aplicável, toda a cópia, parcial ou total, deste documento, nos casos em que é legalmente admitida, deverá conter ou fazer-se acompanhar por este aviso.

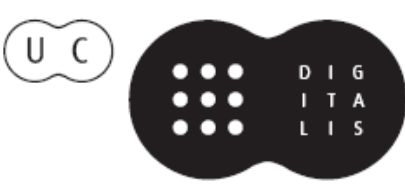




\section{ADVANCES IN}

Forest Fire

\section{RESEARCH}

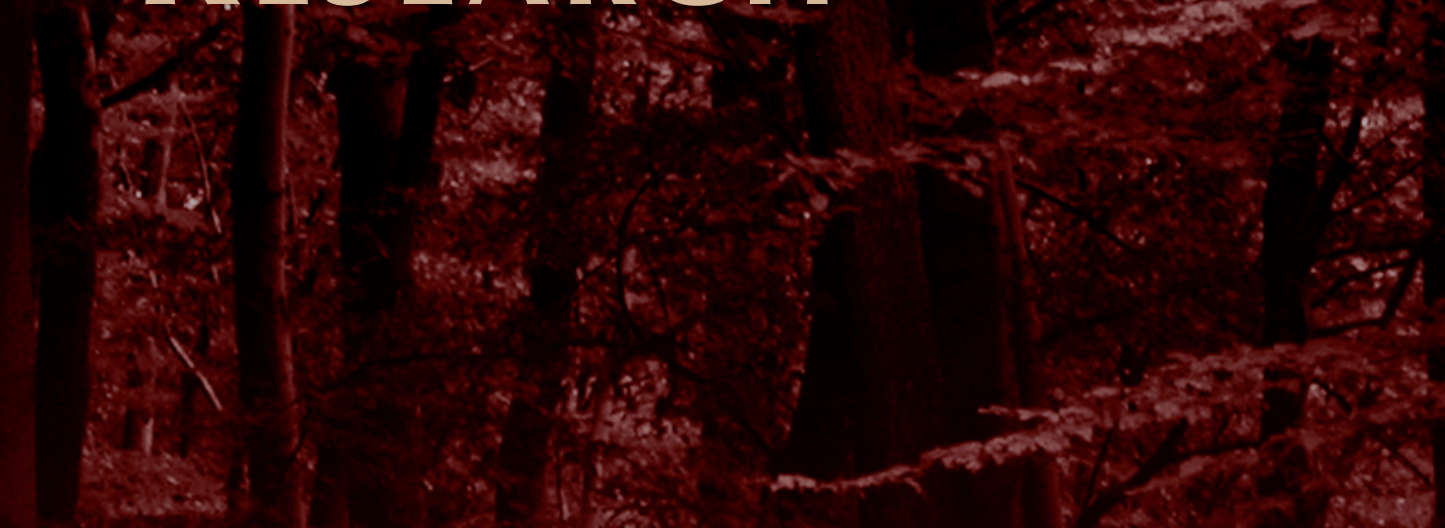

\section{DOMINGOS XAVIER VIEGAS}

\section{EDITOR}




\title{
Assigning dates to burned areas in Portugal based on NIR and the reflected component of MIR as derived from MODIS
}

\author{
Jéssica Panisset ${ }^{\mathrm{a}}$, Renata Libonati ${ }^{\mathrm{b}}$, Carlos C. DaCamara $^{\mathrm{c}}$, Ana Barros ${ }^{\mathrm{c}}$ \\ ${ }^{a}$ Universidade Federal do Rio de Janeiro, Departamento de Meteorologia, Rio de Janeiro - RJ, \\ Brazil - jessicapanisset@gmail.com, leonardo.peres@igeo.ufrj.br \\ ${ }^{b}$ Instituto Nacional de Pesquisas Espaciais, Cachoeira Paulista - SP, Brazil - \\ renata.libonati@cptec.inpe.br \\ ${ }^{c}$ Instituto Dom Luiz / Universidade de Lisboa, Lisboa, Portugal-cdcamara@fc.ul.pt
}

\begin{abstract}
Accurate information about location and extent of burnt area is required and of particular interest for the scientific communities dealing with meteorological and climate models in what respects to reliable estimations of biomass burned. An automated procedure is here presented that allows identifying and assigning dates of occurrence to burned areas in Portugal using daily reflectance from NIR (near-infrared) and MIR (middle infrared) bands, obtained from the MODIS instrument on-board Aqua and Terra satellites. The algorithm detects persistent changes in the so-called $(\mathrm{V}, \mathrm{W})$ Burned Index time series, and the day of maximum change is then identified as the burning day. The procedure was applied to the extreme summer of 2005 and results were validated against a reference map derived from Landsat imagery. Comparison between the burned map as obtained using the developed procedure and the reference map resulted in a Proportion Correct of $96 \%$. Probability of Detection was $63 \%$, meaning that the algorithm was able to identify almost two thirds of the scars occurred in 2005. An assessment of the temporal accuracy of the dating procedure was also conducted. Results show that $75 \%$ of burnt pixels were correctly dated by the algorithm with differences to the hotspots dates less than five days.
\end{abstract}

Keywords: Burned areas, NIR and MIR bands.

\section{Introduction}

Portugal is the European country most prone (per unit area) to fire occurrences, which are responsible for many damages, like the emission of greenhouse gases and pollutants, the loss of vegetation and lives, the soil erosion, the proneness to floods in the period following the fire events and the economic impact, among others.

Instituto de Conservação da Natureza e das Florestas (ICNF), the Portuguese authority for forests, has been producing yearly maps of fire perimeters. The fire atlas uses end of fire season Landsat TM/ETM imagery to map all fire perimeters with areas larger than 5 ha. Because it relies on end-ofseason imagery, the atlas provides a spatial snapshot of the yearly area burned, and dates of burning for individual events cannot be estimated. However, such information is required to fully understand the fire regime and fire seasonality and to disentangle the complex interactions among fire, land cover and meteorology.

The aim of this work is to apply the so-called (V,W) Burned Index in order to identify and assign dates of occurrence to burned areas in Portugal using daily reflectances from NIR (near-infrared) and MIR (middle infrared) bands, obtained from the Moderate Resolution Imaging Spectrometer (MODIS) instrument on-board Aqua and Terra satellites. 


\section{Methods}

\subsection{Data}

Data consist of top of the atmosphere values of MIR radiance, NIR reflectance and thermal infrared (TIR) brightness temperature, acquired by the MODIS instrument on-board Aqua and Terra satellites during July, August and September 2005, together with the respective solar zenith angles. Data were obtained from the Aqua and Terra / MODIS Level 1B $1 \mathrm{~km}$ V5 product, MOD021 and MYD021, (MCST, 2006) and respect to channels 2 (centred at $0.858 \mu \mathrm{m}$ ), 20 (centred at $3.785 \mu \mathrm{m}$ ), and 31 (centred at $11.017 \mu \mathrm{m}$ ). Surface values of MIR reflectance are then retrieved by applying the methodology developed by Kaufman and Remer (1994), paying special attention to the possible drawbacks previously pointed out by Libonati et al. (2010). Data from Aqua and Terra / MODIS Geolocation Fields Level 1A V5 are also used (MOD03 an MYD03).

Validation of results from the analysis performed on MODIS images is mainly carried out based on the annual atlas provided by the ICNF, based on end of fire season Landsat TM/ETM imagery. Validation of the dates assigned is based on the comparison of estimated dates by the developed procedure and dates of hot spots as identified by Modis.

\subsection{The "V,W" Burned Index}

Following the procedure described in Libonati et al. (2011), the "V,W" burned index is computed for each image based on differences ( $\xi$ index) between the reflected component of MIR (middle-infrared, centred at $3.785 \mu \mathrm{m}$ ) and NIR (near-infrared, centred at $0.858 \mu \mathrm{m}$ ) together with the distance ( $\eta$ index) to a convergence point in MIR/NIR space, representative of a totally burned surface. Information of hot spots extracted from the MODIS Fire and Thermal Anomalies Product (MOD14A1/ MYD14A1) is also used.

Coordinate $\mathrm{V}$ has a very small scatter for pixels associated with vegetated surfaces and coordinate $\mathrm{W}$ covers a much wider range of values, allowing the identification of water content of vegetative surfaces.

\subsection{Identification of Burned Areas}

Monthly minimum value composites of $\mathrm{W}$ are computed and seed points of potentially burned areas are selected based on pre-specified thresholds of $\mathrm{W}$ and on temporal differences of $\mathrm{W}$ between composites; seed points also have to be located inside a buffer around MODIS hot spots.

Burned areas are identified by expanding the search around selected seed points. Pixels considered as burned are identified based on relative thresholds whose values are contextually derived from the pixels in the neighbourhood. A spatial filter is finally applied to remove outliers.

\subsection{Assigning dates to burned areas}

The algorithm detects persistent changes in the $(\mathrm{V}, \mathrm{W})$ burned index time series, and the day of maximum change is then identified by means of discrimination index S (Giglio et al., 2009), which estimates the time separability between two groups of $\mathrm{W}$ observations a given day $\mathrm{D}$ (the first group consists in the 6 days before $\mathrm{D}$ and the second one in the 6 days following D). A large and abrupt decrease in the $\mathrm{W}$ values therefore implies positive values of $\mathrm{S}$ that is defined as:

$$
\begin{aligned}
& S(x, y)=\frac{\Delta W(x, y)}{\left[\sigma_{\text {pre }}(x, y)-\sigma_{\text {pos }}(x, y)\right] / 2} \\
& \Delta W(x, y)=\bar{W}_{\text {pre }}(x, y)-\bar{W}_{\text {pos }}(x, y)
\end{aligned}
$$




\section{Results}

Figure 1 shows the values of $\mathrm{W}_{\mathrm{t}}$ and $\Delta \mathrm{W}_{\mathrm{t}(\mathrm{t}-1)} / \mathrm{W}_{\mathrm{t}}$ for July, August and September 2005, as obtained by the algorithm. Burned areas are concentrated in pixels with low values of $\mathrm{W}$ and/or with negative values of $\Delta \mathrm{W}_{\mathrm{t}(\mathrm{t}-1)} / \mathrm{W}_{\mathrm{t}}$ (normalized difference between the value of $\mathrm{W}$ in the current and the previous month), namely pixels whose value of $\mathrm{W}$ has decreased from one month to another.
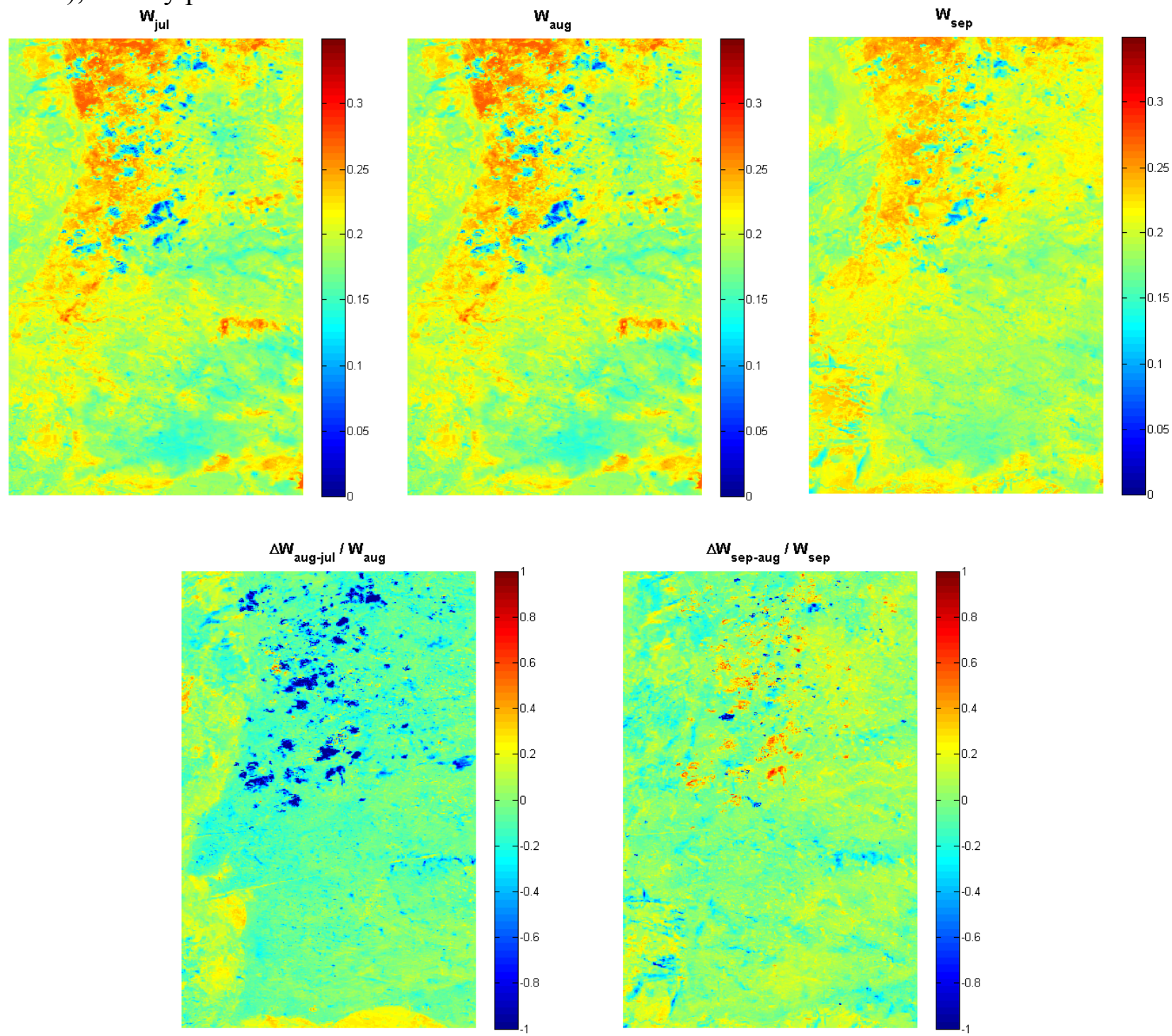

Figure 1. Minimum value composites of W Index for July (upper left panel), August (upper central panel) and September 2005 (upper right panel). Normalized differences between the composites for August and July (lower left panel) and between the composites for September and August (lower right panel).

As mentioned before, fixed thresholds and contextual algorithms are applied to the temporal composites of $\mathrm{W}_{\mathrm{t}}$ and $\Delta \mathrm{W}_{\mathrm{t}(\mathrm{t}-1)} / \mathrm{W}_{\mathrm{t}}$. This methodology is applied to both August and September 2005, resulting in two scar maps that are on the basis of the burned area map of August and September 2005 (Figure 2). 

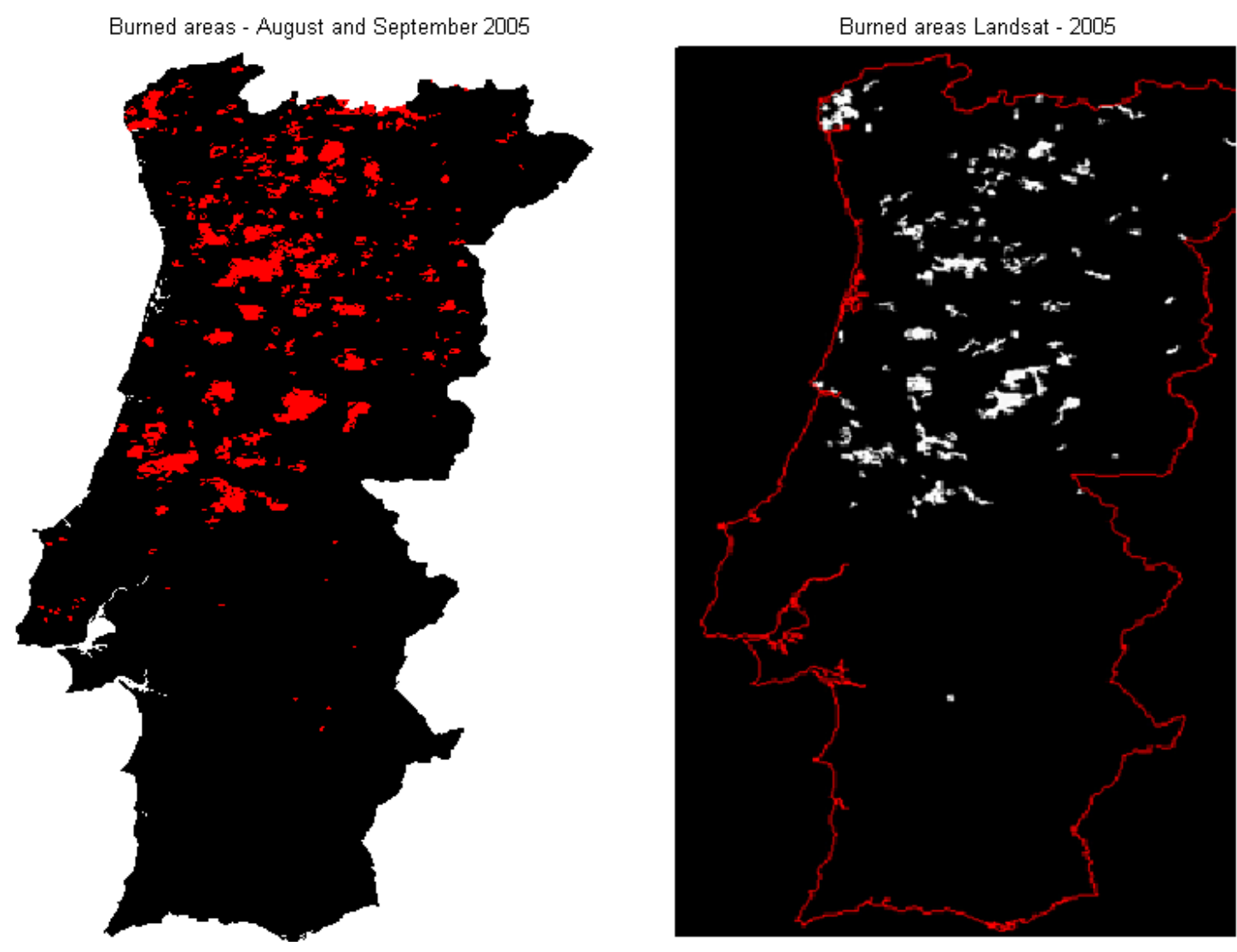

Figure 2. Burned area map for August and September 2005, as obtained by the algorithm based on MODIS imagery (a - left panel) and the reference map for the whole year of 2005, based on Landsat imagery (b - right panel).

Validation of burned area is based on the comparison of the map obtained by the developed algorithm (Figure 2a) with the one derived from scar vectors independently obtained from an end of season Landsat image by ICNF (Figure 2b). For this purpose, the reference map of scar vectors was rasterized to $1 \mathrm{~km}$ resolution, the same of MODIS imagery. In this process, however, some pixels, mainly the ones located in the borders of the scars, do not represent totally burned areas. Because of this, each pixel of the reference map have associated to it a value which represents the percentage of burned area (Figure 3).
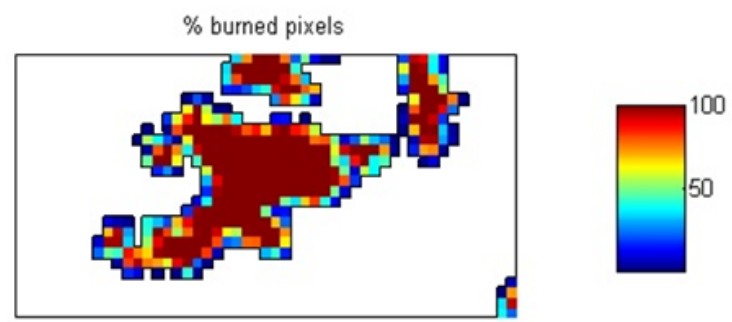

Figure 3. Proportion of burned area in pixels of the reference map, based on Landsat imagery.

Comparison between both maps is performed based on a contingency table (also known as confusion matrix), where all pixels correctly classified are located in the main diagonal, and the incorrect ones, in the remaining cells. The contingency table allows computing a set of accuracy measures, namely Proportion Correct (PC), Commission Error (CE), Omission Error (OE) and Probability of Detection (POD). These measures were computed according to the studies carried out by Binaghi et al. (1999), where agreement or disagreement between reference data (with high resolution) and classified data 
(low resolution) are calculated taking into account the proportion of burned/unburned area of the reference data inside each pixel of classified data. Tables 1 and 2 present the confusion matrix and the accuracy measures, respectively.

Table 1. Contingency table calculated according to studies carried out by Binaghi et al. (1999). Classification was made based on MODIS instrument data, while reference data were based on Landsat imagery.

\begin{tabular}{|c|c|c|c|c|}
\hline & \multicolumn{4}{|c|}{ LANDSAT } \\
\hline \multirow{3}{*}{$\frac{\mathscr{a}}{\hat{0}}$} & & BURNED & UNBURNED & Total \\
\hline & BURNED & 1596.7 & 3165.0 & 4761.7 \\
\hline & UNBURNED & 943.7 & 87765.6 & 88709.4 \\
\hline & Total & 2540.4 & 90930.6 & 93471.0 \\
\hline
\end{tabular}

Table 2. Accuracy measures calculated from the contingency table: Proportion Correct (PC), Commission Error (CE), Omission Error (OE) and Probability of Detection (POD).

\begin{tabular}{cc}
\hline \multicolumn{2}{c}{ Accuracy } \\
\hline Measures \\
\hline CE & $96 \%$ \\
OE & $66 \%$ \\
POD & $63 \%$ \\
\hline
\end{tabular}

The spatial distribution of omission errors, commission errors and hits is presented in Figure 5. Green, red and magenta pixels indicate correctly identified burned areas; commission errors and omission errors, respectively.

According to Table 2, 63\% of burned pixels identified by ICNF (based on the end of fire season Landsat imagery) were correctly classified by the algorithm (based on MODIS imagery). This is a very good result, since the algorithm only detects scars corresponding to August and September, while the reference map refers to the whole year of 2005. In other words, using only images of July, August and September, the algorithm was able to detect more than a half of burned area in the year of 2005.

Cases of omission error represent $37 \%$ of burned pixels of the reference map. Taking into account hotspots dates, it is found that $23 \%$ of all omission errors refer to wildfires occurred in months that are neither August nor September. Therefore, $23 \%$ of all omission errors refer to wildfires that occurred outside the period of imagery used, not being detectable by the algorithm. Most of these cases are related to hotspots detected in July (15), namely the largest scar not detected by the algorithm, highlighted in the right panel of Figure 4. On the other hand, almost 30\% of omissions have an associated hotspot detected in August or September, and should have been identified by the algorithm (Figure 5). Almost half of omission cases occurred in pixels without the presence of hotspots. This may be due to the following three causes:

a) Hotspots used were restricted to those with confidence over $50 \%$;

b) The MODIS algorithm of detection of hotspots failed;

c) The scar map of ICNF may be incorrect in some cases, presenting scars that do not correspond to wildfires (e.g., deforestation). 
Burned area validation - August and September 2005

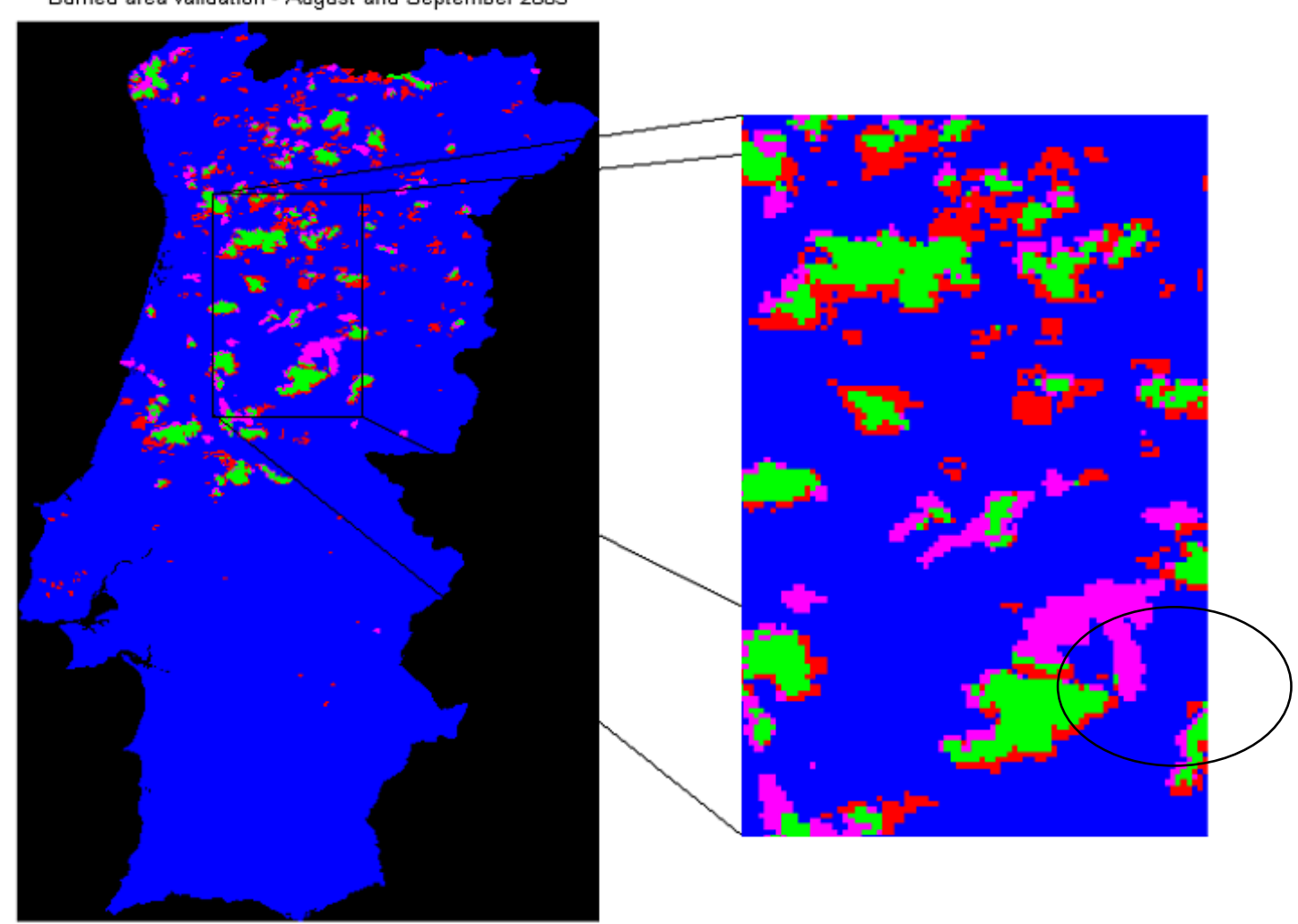

Figure 4. Validation of detection of burned areas. Green pixels indicate agreement between Modis and Landsat; magenta pixels indicate omission errors; red pixels indicate commission errors.

Another important question relates to the proportion of burned pixels area. More than a half (55.4\%) of all omission errors refers to MODIS pixels in which only $1-50 \%$ of the area is burned (Figure 6). These pixels are, therefore, more difficult to be detected by the algorithm that uses low resolution (1 $\mathrm{km})$ data.

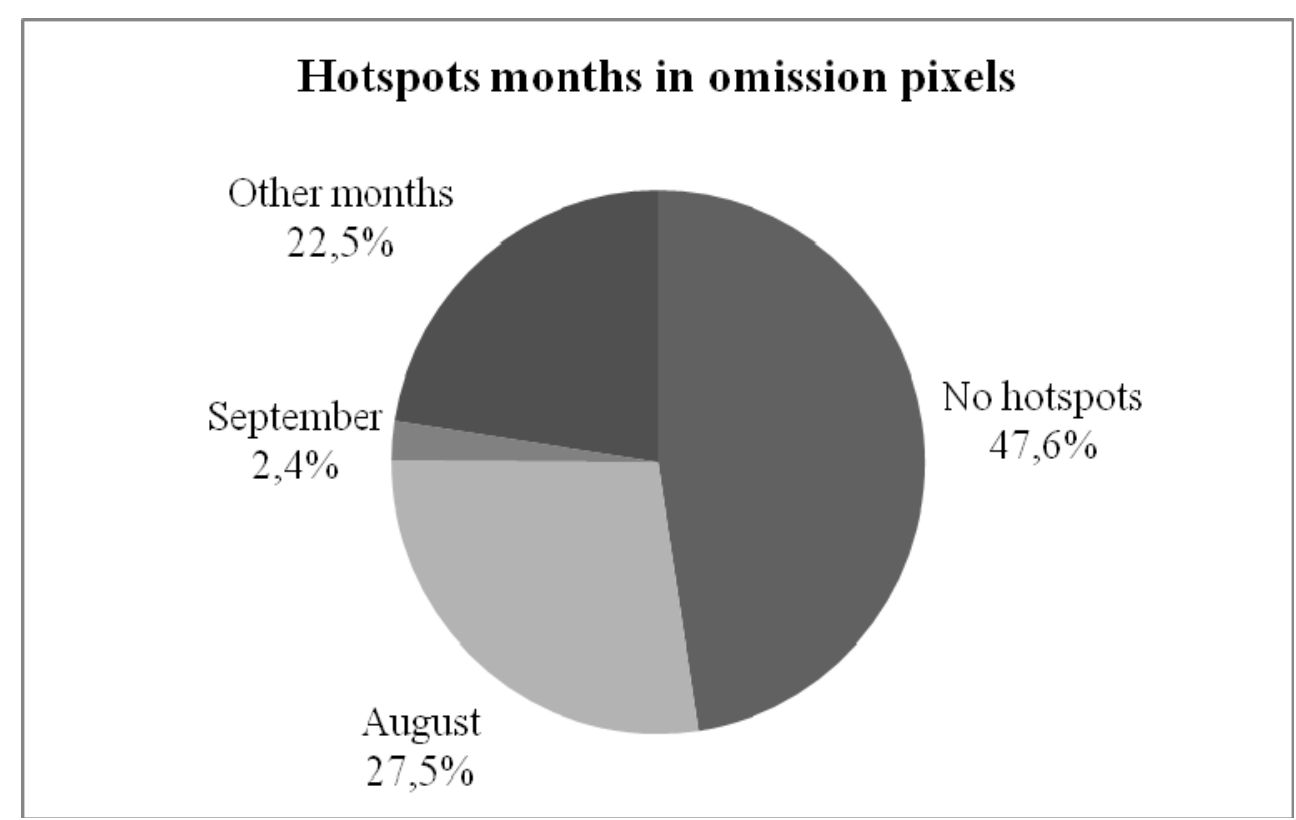

Figure 5. Relative frequency of monthly distribution of hotspots in pixels characterized as omission errors; 62.2\% however, do not have associated hotspots. 


\section{Proportion of burned area in omission pixels}

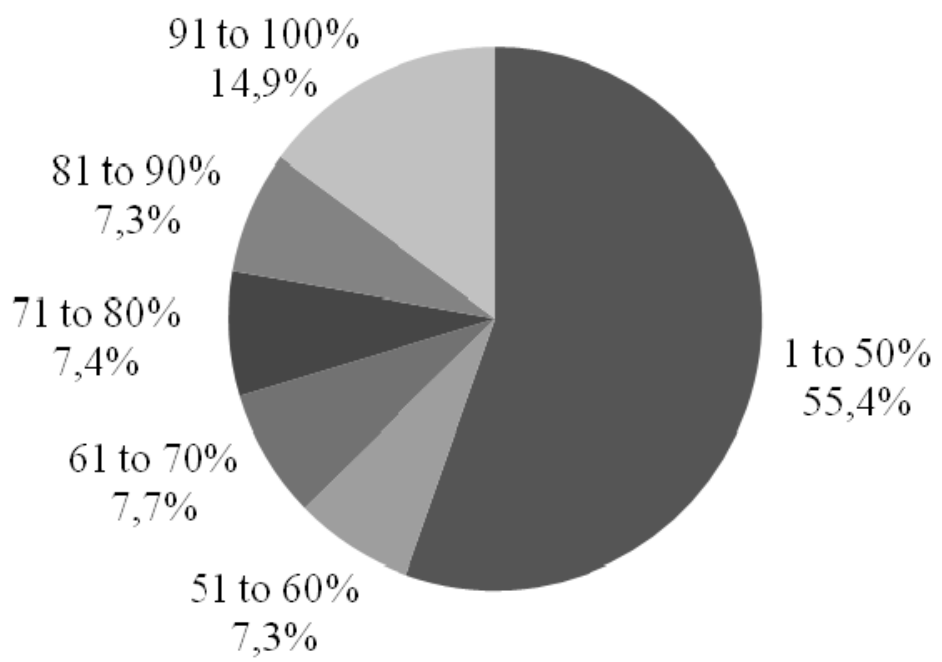

Figure 6. Proportion of burned area of pixels characterized as commission errors. Only $18.4 \%$ correspond to pixels in which 90 to $100 \%$ of the area is burned.

Two thirds (66.5\%) of the pixels detected as burnt by the algorithm were commission errors. However, $14.8 \%$ of them have associated hotspots in August and September (Figure 7). Being classified as burned by the algorithm, these pixels are associated to W low values, and since at least one hotspot has been detected it is quite likely that they have burned in fact; the discrepancies may therefore be due to inaccuracies in the reference map, which, despite having a higher spatial resolution and having been prepared with due care, is also subject to errors, mainly because of its lower temporal resolution.

\section{Hotspots months in commission pixels}

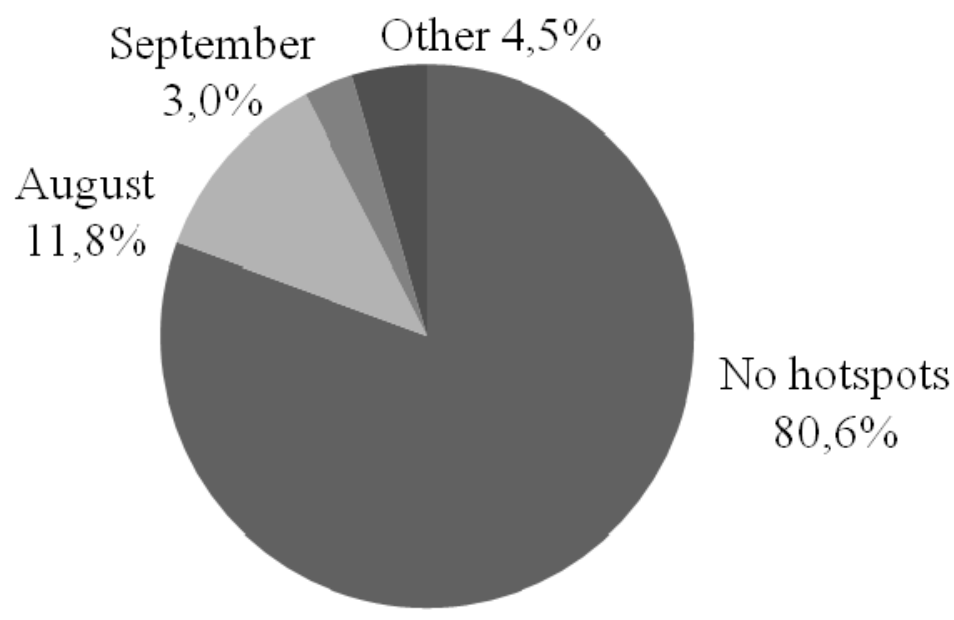

Figure 7. Relative frequency of monthly distribution of hotspots in pixel with commission errors. $20.7 \%$ of commission errors have hotspots in August and September, a possible indication of hit of the algorithm and omission of the reference map. 
Dates assigned by the algorithm are presented in Figure 8. Attribution of dates was only made for pixels correctly identified as burned (left panel); hotspots dates are also presented for the same pixels, when available (right panel). Validation was performed by comparing these dates (between August 1 and September 30). It may be noted that we opted to restrict to hotspots with confidence higher than $50 \%$, so they are supposed to represent wildfires in fact.
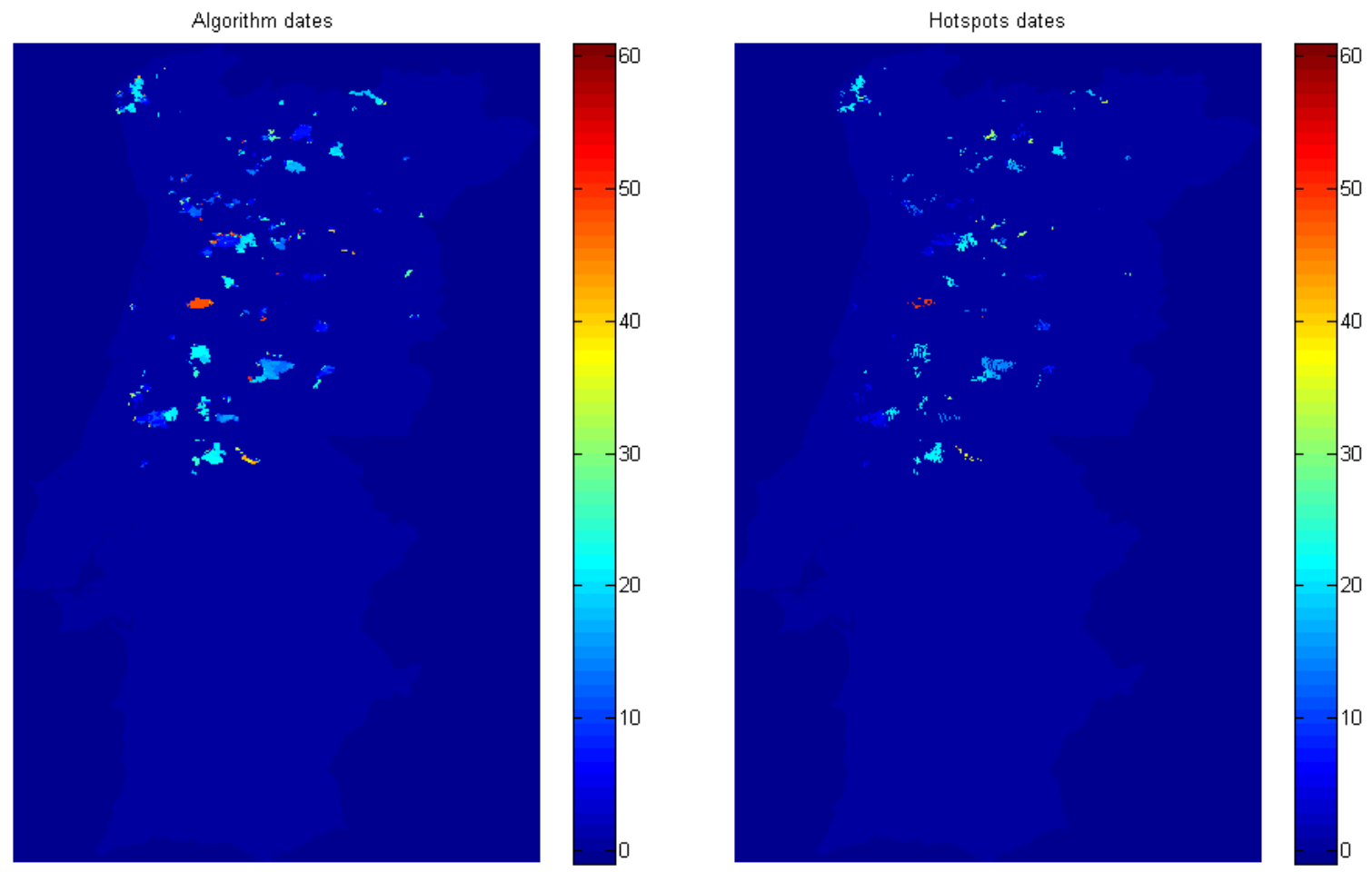

Figure 8. Days of wildfires occurrence. Day 1 refers to August 1, and day 61, to September 30, 2005. Darker blues refer to unburned pixels (zero value) and pixels outside Portugal (negative values) (left panel). On the right panel, are presented days of occurrence of hotspots in the same pixels, when available.

Comparison of estimated dates by our procedure and dates of hotspots as identified by MODIS showed that more than $3 / 5$ of cases $(63.5 \%)$ have differences between -2 and +2 days and that $3 / 4$ of cases $(75.0 \%)$ have differences between -5 and +5 days (Figure 9 ).

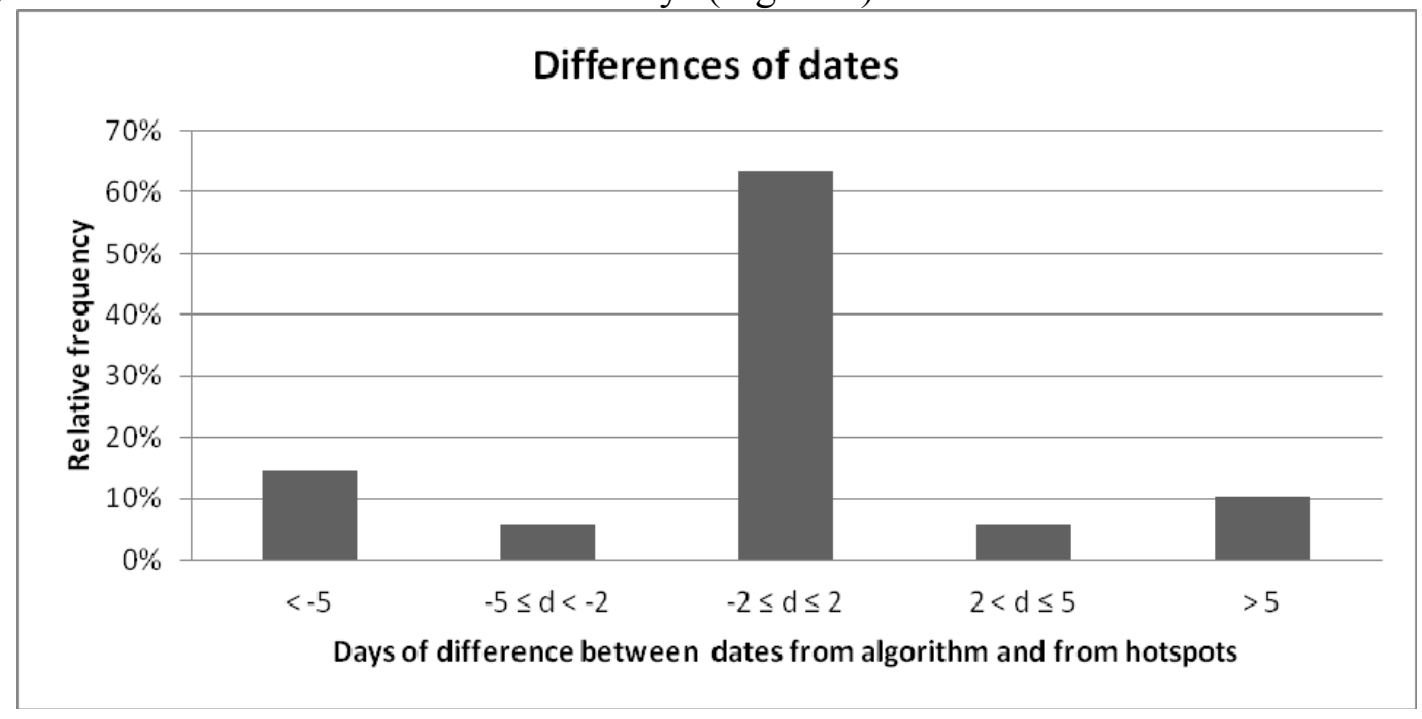

Figure 9. Differences between dates assigned by the algorithm and dates of hotspots occurrence. $75 \%$ of dates were correctly attributed. 


\section{Discussion}

A new automated method of detection and of date assignment to burned areas was applied to Portugal, based on daily reflectances from NIR (near-infrared) and MIR (middle infrared). A total of 170 images from MODIS instrument on-board Aqua and Terra satellites were used during July, August and September 2005, the second worst year in terms of burned area in Portugal.

The algorithm uses MIR and NIR information to calculate the $(\mathrm{V}, \mathrm{W})$ Burned Index. Burned pixels are identified by means of fixed and contextual thresholds on monthly composites, and burned area maps are generated. Comparison between generated and reference maps, the latter based on end of fire season Landsat imagery resulted in an agreement of 95.6\%, and a Probability of Detection of 62.9\%, which means that with only low resolution images for July, August and September, the automated procedure was able to detect almost two thirds of all scars occurred in 2005.

Omission and commission errors were observed mainly on the scars borders, where the proportion of burned area is not so large and the spectral signal on the W Index is not so pronounced. Commission errors were also observed in isolated scars, generally small ones and associated to hotspots. It is possible that these cases are actually omission errors of the reference map and hits by the algorithm. This would be possible given the fact that the reference map is based on end of fire season imagery, when the radiometric signal of some small scars could have been already extinguished. Besides, the lower temporal resolution of Landsat when compared to MODIS, naturally leads to a smaller number of available images.

Omission errors were also observed in isolated scars, generally large ones. Analyzing dates of hotspots in these pixels, when available, it was noted that these undetected scars correspond to wildfires that have not occurred in August and September. Notably the greatest scar, located in the central of the country, in which hotspots indicate wildfires occurred in July. Therefore it was not supposed to be detected by the algorithm.

The attribution of dates to the scars was made based on analysis of W Index values, being the day with the greatest variation (greatest temporal separability) considered the day of burn. Validation shown that $63.5 \%$ of the pixels were correctly dated, with differences of the hotspots occurrence between -2 and +2 days. Allowing differences of up to 5 days, the matching score increases to $75.0 \%$.

Results from this work open very promising perspectives towards the operational identification and the assignment of dates to burned areas, therefore contributing to a better understanding of fire regimes.

\section{References}

Barbosa, P. M., Grégoire, J. M., \& Pereira, J. M. C. (1999). An algorithm for extracting burned areas from time series of AVHRR GAC data applied at a continental scale. Remote Sensing of Environment, 69(3), 253-263.

Binaghi, E., Brivio, P. A., Ghezzi, P., \& Rampini, A. (1999). A fuzzy set-based accuracy assessment of soft classification. Pattern recognition letters,20(9), 935-948.

Boyd, D. S., \& Duane, W. J. (2001). Exploring spatial and temporal variation in middle infrared reflectance (at 3.75@m) measured from the tropical forests of west Africa. International Journal of Remote Sensing, 22(10), 1861-1878 apud Libonati, 2010.

Direcção Geral Dos Recursos Florestais. Incêndios Florestais - Relatório de 2005. Lisboa, 2006. 27p. Available at: <http://www.icnf.pt/portal/florestas/dfci/Resource/doc/rel/if-rel2005.pdf>. Last visited: 2014, 26 January.

Earth Observing System Data and Information System. Near Real-Time Data - FAQ. Available at: $<$ https://earthdata.nasa.gov/data/near-real-time-data/faq/firms $>$. Last visited: 2014, 05 March.

Fraser, R. S., \& Kaufman, Y. J. (1985). The relative importance of aerosol scattering and absorption in remote sensing. Geoscience and Remote Sensing, IEEE Transactions on, (5), 625-633. 
Giglio, L., Loboda, T., Roy, D. P., Quayle, B., \& Justice, C. O. (2009). An active-fire based burned area mapping algorithm for the MODIS sensor. Remote Sensing of Environment, 113(2), 408-420.

Holben, B. N. (1986). Characteristics of maximum-value composite images from temporal AVHRR data. International Journal of Remote Sensing, 7(11), 1417-1434.

Kaufman, Y. J., \& Remer, L. A. (1994). Detection of forests using mid-IR reflectance: an application for aerosol studies. Geoscience and Remote Sensing, IEEE Transactions on, 32(3), 672-683.

Libonati, R., DaCamara, C. C., Pereira, J. M., Setzer, A., \& Morelli, F. (2007). A New Optimal Index for Burnt Area Discrimination in Satellite Imagery. In2007 EUMETSAT Meteorological Satellite Conference and the 15th Satellite Meteorology \& Oceanography Conference of the American Meteorological Society.

Libonati, R., DaCamara, C. C., Pereira, J. M. C., \& Peres, L. F. (2011). On a new coordinate system for improved discrimination of vegetation and burned areas using MIR/NIR information. Remote Sensing of Environment, 115(6), 1464-1477.

Libonati, R., DaCamara, C. C., Pereira, J. M. C., \& Peres, L. F. (2010). Retrieving middle-infrared reflectance for burned area mapping in tropical environments using MODIS. Remote Sensing of Environment, 114(4), 831-843.

Libonati, R., DaCamara, C. C., Pereira, J. M. C., \& Peres, L. F. (2012). Retrieving middle-infrared reflectance using physical and empirical approaches: implications for burned area monitoring. Geoscience and Remote Sensing, IEEE Transactions on, 50(1), 281-294.

Libonati, R. Using middle-infrared reflectance for burned area detection. 2010. 182 p. Tese (Doutorado em Ciências Geofísicas e da Geoinformação - Meteorologia) - Faculdade de Ciências, Universidade de Lisboa, Lisboa, 2010.

Libonati, R. (2010). Using middle-infrared reflectance for burned area detection.Ph.D. dissertation, University of Lisbon, Lisbon, Portugal.

Libonati, R.; Setzer, A. W.; Morelli, F. Algoritmo automático de detecção de áreas queimadas em imagens MODIS - aplicação na região de Jalapão, TO. In: Proceedings of XVI Simpósio Brasileiro de Sensoriamento Remoto. Foz do Iguaçu, 2013.

Mieville, A., Granier, C., Liousse, C., Guillaume, B., Mouillot, F., Lamarque, J. F., ... \& Pétron, G. (2010). Emissions of gases and particles from biomass burning during the 20th century using satellite data and an historical reconstruction. Atmospheric Environment, 44(11), 1469-1477.

National Aeronautics and Space Administration. About Modis. Available at: < http://modis.gsfc.nasa.gov/about/>. Last visited: 2014, 24 February.

Pereira, J. M. (1999). A comparative evaluation of NOAA/AVHRR vegetation indexes for burned surface detection and mapping. Geoscience and Remote Sensing, IEEE Transactions on, 37(1), 217 226.

Pereira, M. G., Calado, T. J., DaCamara, C. C., \& Calheiros, T. (2013). Effects of regional climate change on rural fires in Portugal. Climate research,57(3), 187-200.

Pereira, M. G., Trigo, R. M., da Camara, C. C., Pereira, J., \& Leite, S. M. (2005). Synoptic patterns associated with large summer forest fires in Portugal. Agricultural and Forest Meteorology, 129(1), 11-25.

Pereira, M. G., Malamud, B. D., Trigo, R. M., \& Alves, P. I. (2011). The history and characteristics of the 1980-2005 Portuguese rural fire database.Natural Hazards and Earth System Science, 11(12), 3343-3358.

Roy, P. S. (2003). Forest fire and degradation assessment using satellite remote sensing and geographic information system. Satellite Remote sensing and GIS applications in agricultural meteorology, 361.

Roy, D. P. (1999). Multi-temporal active-fire based burn scar detection algorithm. International Journal of Remote Sensing, 20(5), 1031-1038.

Verstraete, M. M., \& Pinty, B. (1996). Designing optimal spectral indexes for remote sensing applications. Geoscience and Remote Sensing, IEEE Transactions on, 34(5), 1254-1265. 